\section{PSIHOSOCIJALNI ASPEKTI GRANIČNOG POREMEĆAJA LIČNOSTI}

Pregledni članak

Primljeno: veljača, 2019.

Prihvaćeno: srpanj, 2019.

UDK 364.62:364.65-056.34

DOI 10.3935/ljsr.v26i2.286

Ivana Maljuna ${ }^{1}$

orcid.org/0000-0001-9144-2186

Draženka Ostojić ${ }^{2}$

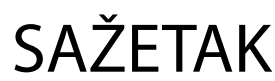

Granični poremećaj ličnosti najčešće se javlja u kasnoj adolescenciji ili mlađoj odrasloj dobi, a njegova najjasnija prezentacija je u odrasloj dobi, nakon završetka psihološkog sazrijevanja. Simptomi ovog poremećaja manifestiraju se nestabilnim afektom, impulzivnim ponašanjem, poremećajem identiteta, nestabilnim interpersonalnim odnosima i mogućim pogreškama u testiranju realnosti što sve može rezultirati značajnim poteškoćama osobnog, obiteljskog, roditeljskog, socijalnog i radnog funkcioniranja. Prognostički dodatnu otegotnu okolnost predstavljaju i česti komorbiditeti (afektivni poremećaji, anksioznost i zlouporaba sredstava ovisnosti itd). Etiološki čimbenici poremećaja su mnogobrojni i nedovoljno poznati, a na razini današnjih saznanja uključuju interakciju bioloških predispozicija i okolišnih faktora. U liječenju i skrbi za osobe s graničnim poremećajem ličnosti, uz psihoterapiju i socioterapiju (i po potrebi farmakoterapiju), neophodna je $i$ primjena sveobuhvatnih psihosocijalnih intervencija pri čemu ključnu ulogu imaju socijalni radnici. Pravodobno prepoznavanje etioloških čimbenika i poduzimanje mjera iz nadležnosti socijalnih radnika u okviru sustava socijalne skrbi može pridonijeti prevenciji javljanja ovog poremećaja ličnosti, dok mjere orcid.org/0000-0003-1796-6867

Tihana Jendričko ${ }^{3}$ Klinika za psihijatriju Vrapče, Zagreb

orcid.org/0000-0001-5197-943X

Ključne riječi:

granični poremećaj

ličnosti, socijalni radnik, psihosocijalne intervencije.

Ivana Maljuna, magistrica socijalnog rada,

e-mail: ivana.maljuna1@gmail.com

2 Doc. dr. sc. Draženak Ostojić, specijalistica psihijatrije, e-mail:drazenkaostojic@gmail.com

3 Doc. dr. sc. Tihana Jendričko, specijalistica psihijatrije e-mail: tjendricko@gmail.com 


\section{i intervencije koje se primjenjuju prema oboljelim osobama mogu pomoći u njihovoj rehabilitaciji i dobrobiti, kao i dobrobiti članova njihove obitelji.}

\section{UVOD}

Pojam »ličnost« koristi se da bi se opisao središnji dio ljudske prirode. Jedna od najprihvaćenijih definicija ličnosti je Larsenova i Bussova (2008.) prema kojoj je ličnost »skup psihičkih osobina i mehanizama unutar pojedinca koji su organizirani i relativno trajni, te utječu na interakcije i adaptacije pojedinca na intrapsihičku, fizičku i socijalnu okolinu«.

Za razliku od »zdrave« ličnosti, poremećaji ličnosti obuhvaćaju široki spektar obilježja iz kojih proizlaze duboko ukorijenjeni trajni obrasci ponašanja koja se očituju kao nefleksibilno reagiranje u različitim socijalnim i osobnim situacijama (Mimica i Gregurek, 2006.). Riječ je o ponašanju koje je različito od očekivanog (»patološko«), perzistirajuće (učestalo javljanje tijekom razdoblja od najmanje pet godina) i pervazivno (javljanje određenog ponašanja u različitim situacijama) (Begić, 2011.). Pri tome je važno naglasiti da se poremećaji ličnosti, u svojoj osnovi, ne ubrajaju u »prave« duševne bolesti (poput, primjerice, psihotičnih poremećaja, depresije, bipolarnog afektivnog poremećaja i dr.). Radi se o razvojnim stanjima čija se obilježja najčešće uočavaju u adolescenciji, iako pojavnost nije rijetka ni u djetinjstvu, a njihova najjasnija prezentacija je u odrasloj dobi, nakon »završetka« psihološkog sazrijevanja. Osoba sa znakovima poremećaja ličnosti doživljava subjektivnu nelagodu i probleme u socijalnom funkcioniranju i radu (Mimica i Gregurek, 2006.) iz čega proizlaze i negativne konotacije poremećaja ličnosti na sve aspekte života pojedinca, a što je posebice prisutno kod osoba s graničnim poremećajem ličnosti (eng. borderline personality disorder) (Gunderson i Links, 2008.).

\section{CILJ RADA}

Cilj rada je istaknuti važnost prepoznavanja osoba s graničnim poremećajem ličnosti kroz pregled temeljnih odrednica ovog poremećaja na području etiologije, kliničke slike, liječenja i psihosocijalnih tretmana s posebnim naglaskom na aktivnosti socijalnih radnika u skrbi za osobe s ovim poremećajem. Naime, osobe s graničnim poremećajem ličnosti nerijetko su potrebite različitih intervencija socijalne službe zbog čitavog niza mogućih nepovoljnih psihosocijalnih implikacija koje proizlaze iz karakteristika ličnosti i posljedičnih problema na planu osobnog, obiteljskog, roditeljskog, socijalnog i radnog funkcioniranja.

\section{4 članci}




\section{RAZVOJ KONCEPTA GRANIČNOG POREMEĆAJA LIČNOSTI}

Pojam »granične ličnosti« prvi je upotrijebio Adolph Stern 1938. godine da bi opisao skupinu pacijenata koja se nalazi na granici između psihotičnih i neurotičnih poremećaja (Gunderson i Links, 2008.). Kernberg 1975. godine uvodi pojam »granične organizacije ličnosti« (eng. borderline) koju karakterizira neuspjeh u formiranju identiteta ili slabo formiran identitet, primitivni obrambeni mehanizmi (cijepanje, projekcija i identifikacija) te pogrešno testiranje realnosti pod utjecajem stresa (Gunderson i Links, 2008.). Grinker i sur. u radu »Granični sindrom« (eng. borderline syndrome) prvi su predložili empirijski utemeljene dijagnostičke kriterije graničnog sindroma: neuspjehe u formiranju identiteta, anaklitičke odnose, depresiju utemeljenu na osamljenosti i dominantnu izraženu agresiju (Grinker i sur., 1968., prema Gunderson i Links, 2008.). Skupinu karakteristika prema kojima se danas dijagnosticira granični poremećaj ličnosti i koja je inkorporirana u psihijatrijske klasifikacije opisali su Gunderson i Kolb 1978. godine. Dijagnoza graničnog poremećaja ličnosti prvi put je uvedena u 3. izdanju Dijagnostičkog i statističkog priručnika (DSM-III) Američke psihijatrijske udruge iz 1980. godine čime su uspostavljeni standardizirani dijagnostički kriteriji za granični poremećaj ličnosti, dok se u Međunarodnu klasifikaciju bolesti i srodnih zdravstvenih problema (MKB) Svjetske zdravstvene organizacije uvodi 1992. godine (Gunderson i Links, 2008.).

\section{POJAVNOST GRANIČNOG POREMEĆAJA LIČNOSTI}

Smatra se da prevalencija graničnog poremećaja ličnosti u općoj populaciji iznosi između 1\% i 2\% (Torgersen i sur., 2001., prema Gunderson i Hoffman, 2005., Gunderson i Links, 2008.), pri čemu pojavnost poremećaja kod žena i muškaraca iznosi 3:1, što se povezuje s podacima prema kojima žene češće traže psihosocijalnu pomoć (Kreisman i Straus, 2004.). Novije studije sugeriraju da se pojavnost graničnog poremećaja ličnosti između muškaraca i žena ne razlikuje. Podaci ukazuju da, u odnosu na muškarce, veći broj žena traži neki od oblika psihosocijalne pomoći što može biti posljedica razlika u kliničkim prezentacijama graničnog poremećaja ličnosti kod žena i muškaraca. Tako su, primjerice, kod žena češće izraženi simptomi depresivnosti, anksioznosti, somatizacije (Silberschmidt i sur., 2015.), afektivne nestabilnosti, kronični osjećaj praznine, suicidalno ponašanje i samoozljeđivanje (Hoertel i sur., 2014., prema Holthausen i Habel, 2018.), dok su kod muškaraca prisutne veće stope antisocijalnog, narcisoidnog (Silberschmidt i sur., 2015.; Sher i sur., 2019.), paranoidnog i shizotipnog poremećaja ličnosti (Sher i sur., 2019.), impulzivnosti (Hoertel i sur., 2014., prema Holtahusen i Habel, 2018.; Sher i sur., 2019.), agresije, 
uključujući fizičku agresiju, zlouporabe alkohola i drugih psihoaktivnih tvari (Sher i sur., 2019.). Navedeno determinira i potrebite oblike intervencija (psihijatrijske ustanove, korektivne i rehabilitacijske ustanove itd). Procjenjuje se da osobe s graničnim poremećajem ličnosti čine oko $10 \%$ od ukupnog broja ambulantno liječenih pacijenata, dok njihov udio među bolnički liječenim pacijentima može biti i veći (Widiger i Frances, 1989., prema Gunderson i Hoffman, 2005.). Navedeno je značajno determinirano autodestruktivnim i suicidalnim ponašanjem te komorbiditetom $s$ drugim psihičkim poremećajima (primjerice, afektivni poremećaji, anksioznost i zlouporaba psihoaktivnih sredstava).

\section{ETIOLOGIJA GRANIČNOG POREMEĆAJA LIČNOSTI}

Suvremene znanstvene spoznaje etiologije graničnog poremećaja, na razini današnjih saznanja, nisu posve jednoznačne i nedvojbene. Za potrebe ovog rada izdvojit ćemo one najzastupljenije - biološke, psihosocijalne i one koje obuhvaćaju njihovo međudjelovanje.

Biološke osnove poremećaja sagledavaju se kroz genetsku predispoziciju i moguće strukturalne i kemijske promjene mozga. O utjecaju genetskih predispozicija na razvoj poremećaja ličnosti govore istraživanja provedena na blizancima. Prema rezultatima jednog od tih istraživanja javljanje poremećaja ličnosti kod jednojajčanih blizanaca iznosi 52\%, a kod višejajčanih 22\% (Mimica i Grekurek, 2006.). Rezultati jedne od studija pokazali su da se genetski prijenos očituje kroz crte afektivne nestabilnosti i impulzivnosti, sklonosti samoozljeđivanju i mogućih problema identiteta (Hoffman i McGlashan, 2003.). Obiteljske studije pokazale su da srodnici osobe s graničnim poremećajem ličnosti imaju pet puta veći rizik javljanja poremećaja u odnosu na opću populaciju, pri čemu članovi obitelji imaju veću šansu i za ispunjavanje dijagnostičkih kriterija srodnih bolesti kao što su bolesti ovisnosti, afektivni poremećaji i disocijalni poremećaj ličnosti (Kreisman i Straus, 2004.).

Smatra se također da ulogu u razvoju graničnog poremećaja ličnosti imaju promjene limbičkog sustava koji utječe na pamćenje, učenje, emocionalna stanja i ponašanja. Nalazi magnetske rezonance (MRI) kod žena s graničnim poremećajem ličnosti koje su proživjele traumu pokazali su smanjenje volumena limbičkog sustava, osobito u području amigdale i hipokampusa (Kreisman i Straus, 2004.). Također, kod osoba s ovim poremećajem uočene su promijenjene aktivnosti u nekim drugim područjima mozga (Schmahl i sur., 2003.; Herpertz i sur., 2001.; Donegan i sur., 2003., prema National Collaborating Centre For Mental Health, 2009.) pri čemu je potrebno naglasiti da opisane promjene nisu posve specifične za granični poremećaj ličnosti kao ni mogući neurotransmitorski disbalansi. Naime, istraživanja ukazuju da razina

\section{6 članci}


serotonina, dopamina, gaba-aminomaslačne kiseline (GABA), acetikolina i noradrenalina potencijalno determinira neke od simptoma ovog poremećaja (Kreisman i Straus, 2004., Begić, 2011.).

Psihosocijalne teorije uzroka graničnog poremećaja ličnosti u fokus stavljaju iskustva u djetinjstvu, prvenstveno doživljeno zanemarivanje i zlostavljanje. Procjenjuje se da je između 60\% i 90\% osoba s graničnom strukturom ličnosti u dječjoj dobi doživjelo neki od oblika zlostavljanja (Gabbard, 1990., prema Begić, 2011.). Njih $71 \%$ doživjelo je fizičko nasilje, $68 \%$ seksualno, a $62 \%$ svjedočilo je obiteljskom nasilju (Herman i sur., 1988., prema Black i sur., 2008.). Smatra se da iskustvo zlostavljanja u dječjoj dobi može izazvati simptome posttraumatskog stresnog sindroma čemu se osoba tijekom odrastanja »prilagođava« te se ti simptomi transformiraju i inkorporiraju u strukturu ličnosti (Hoffman i McGlashan, 2003.). Također, disfunkcionalnost roditelja može predstavljati značajan etiološki čimbenik, posebice u kontekstu (ne) primjerene privrženosti (eng. attachment). Naime, obrasci odnosa roditelja i djeteta, koji su osnova razvoja sigurnosti, samopouzdanja i samostalnosti djeteta, rezultiraju stvaranjem emocionalnih veza (Bowlby, 1990., prema Beauchaine, Crowell i Linehan, 2009.). Stoga, visoka učestalost poremećaja privrženosti kod odraslih osoba s graničnim poremećajem ličnosti, koji karakteriziraju zlostavljanje, zanemarivanje, odbijanje, izostanak podrške, pretjerana kontrola, izostanak povezanosti i zbunjenost (Levy, 2005., prema National Collaborating Centre For Mental Health, 2009.) ukazuje da je poremećaj privrženosti u djetinjstvu mogući čimbenik koji pridonosi vulnerabilnosti za razvoj ovog poremećaja.

Važno je napomenuti da i psihički poremećaji roditelja mogu reducirati njihov senzibilitet za dječje potrebe i dostupnost djetetu, pri čemu se smatra da majke s graničnim poremećajem ličnosti iskazuju nedostatnu reaktibilnost na djetetovo iskazivanje emocija (Elliot i sur., 2014.), da prisutnost paranoidnih, narcisiodnih i antisocijalnih obilježja roditelja može povećati rizik za zlostavljanje djeteta, dok depresija može negativno utjecati na roditeljsku emocionalnost i emocionalni odgovor. Također, značajan utjecaj na razvoj djeteta ima i kvaliteta međusobnog odnosa roditelja, učestalost verbalnih i fizičkih sukoba roditelja te (ne)suglasje oko skrbi o djetetu (Hoffman i McGlashan, 2003.).

$S$ duge strane, sociokulturalni čimbenici mogu imati protektivnu ulogu (povezano društvo, proširena obiteljska mreže, kultura koja stavlja naglasak na važnost interpersonalne privrženosti i povezanosti i sl.), ali mogu predstavljati i rizični čimbenik. Neki od rizičnih čimbenika su promijenjene i promjenjive društvene uloge i očekivanja, gubitak proširene obitelji, društveni slom te socijalno prihvaćanje konzumacije različitih psihoaktivnih tvari. Nesumnjivo je da se političke, ekonomske i društvene okolnosti reflektiraju na roditeljstvo, socijalnu potporu i društvene norme 
s posljedičnim utjecajem na stilove privrženosti, formiranje identiteta, kogniciju te ponašajne i interpersonalne strategije (primjerice, društveni i ekonomski pritisci mogu pridonijeti smanjenju roditeljske osjetljivosti i odgovora na dječje potrebe) (Murphy i McVay, 2010.). Kao mogući etiološki čimbenici navode se i siromaštvo i socioekonomski status koji u interakciji s karakteristikama pojedinca mogu rezultirati javljanjem psiholoških problema (Družić Ljubotina i Ljubotina, 2014.). Prema rezultatima istraživanja Granta i suradnici (2008.), stope graničnog poremećaja ličnosti povećane su kod osoba koje su razdvojene, razvedene, udovci/udovice, kao i kod osoba s nižim obrazovanjem i socioekonomskim statusom. Dobiveni rezultati u skladu su s rezultatima istraživanja Choen i suradnici (2008.) koji pokazuju da nizak socioekonomski status, udružen s drugim rizicima, doprinosi intenziviranju simptoma graničnog poremećaja ličnosti, odnosno što je više simptoma graničnog poremećaja ličnosti prisutno kod pojedinca, veća je vjerojatnost da on/ona ne živi s partnerom i nema plaćen posao (ten Have i sur., 2016.).

Jedna od najprihvaćenijih etioloških teorija graničnog poremećaja ličnosti je ona Marshe Lienhan iz 1993. godine. Prema ovoj teoriji, granični poremećaj ličnosti prvenstveno se odnosi na poremećaj emocionalne regulacije koji je posljedica transakcije između biološke vulnerabilnosti pojedinca i nepovoljnih utjecaja iz okoline. Osobe s ovim poremećajem suočavaju se s pojačanom emocionalnom osjetljivošću, nemogućnošću reguliranja intenzivnih emocionalnih reakcija i sporim povratkom na osnovnu emocionalnu vrijednost. Emocionalna regulacija obuhvaća kognitivne procese povezane semocijama, biokemijske i fiziološke procese, facijalnu ekspresiju is emocijama povezane akcije. Ova je teorija potkrijepljena i drugim istraživanjima prema kojima emocionalna disregulacija rezultira disfunkcionalnim obrascima odgovora na emocionalno izazvane događaje (Linehan, 1993., prema Crowell, Beauchaine i Linehan, 2009.). Granični poremećaj ličnosti razvija se unutar nepodržavajućeg razvojnog konteksta koji karakterizira netrpeljivost prema ekspresiji emocionalnih doživljaja pri čemu takva okolina može privremeno osnažiti ekstremne izraze emocija istovremeno šaljući poruku da su isti neopravdani i neprimjereni te da se s njima treba nositi interno i bez roditeljske podrške. Posljedično, dijete ne uči imenovati, regulirati i/ili tolerirati emocionalne odgovore, već uči oscilirati između emocionalne inhibicije i ekstremne emocionalne nestabilnosti (Beauchaine, Crowell i Linehan, 2009.).

\section{KLINIČKA SLIKA I POSTAVLJANJE DIJAGNOZE GRANIČNOG POREMEĆAJA LIČNOSTI}

Simptomi graničnog poremećaja ličnosti najčešće se javljaju u kasnoj adolescenciji ili mlađoj odrasloj dobi (National Collaborating Centre For Mental Health,

\section{8 članci}


2009.), premda ozbiljni problemi separacije i ispadi bijesa djece mlađe dobi mogu upućivati na mogući razvoj graničnog poremećaja ličnosti i mogu biti dijagnostički indikativni (Kresiman i Straus, 2004.). Većina osoba s graničnim poremećajem ličnosti u tridesetim i četrdesetim godinama života dostigne zadovoljavajuću stabilnost, međutim poremećaj perzistira i u starijoj životnoj dobi, ali u znatno manjoj mjeri (Kreisman i Straus, 2004.).

Dijagnoza graničnog poremećaja ličnosti postavlja se sukladno važećim klasifikacijama psihičkih poremećaja - Desetoj reviziji Međunarodne klasifikacije bolesti i srodnih zdravstvenih problema (MKB-10) (Svjetska zdravstvena organizacija, 2010.) te Dijagnostičkom i statističkom priručniku za mentalne bolesti DSM-5 Američke psihijatrijske udruge (eng. American Psychiatric Association, APA) (2014.) U MKB-10 granični poremećaj ličnosti svrstan je u potkategoriju poremećaja ličnosti - »emocionalno nestabilna ličnost« (F60.3).

Prema MKB-10 kriterijima, emocionalno nestabilnu ličnost karakterizira tendencija impulzivnim radnjama bez razmišljanja o posljedicama i afektivna nestabilnost. Prisutna je sklonost ljutnji i svađama, teškoće u kontroli impulzivnih radnji, osobito kada naiđu na kritiziranje ili ometanje od strane okoline. Postoje dva tipa ovog poremećaja: impulzivni tip karakteriziran emocionalnom nestabilnošću i nemogućnošću kontrole uz učestale napade prijetećeg i nasilnog ponašanja kao odgovora na kritiku, te granični tip kod kojeg su prisutne dodatne poteškoće, kao što su poremećaj predodžbe slike o sebi, ciljevima i unutarnjim prioritetima, kronični osjećaj praznine, intenzivni i nestabilni interpersonalni odnosi, autodestruktivno ponašanje, uključujući prijetnje suicidom i pokušaje suicida.

Prema DSM-5, granični poremećaj ličnosti odnosi se na pervazivni obrazac nestabilnosti u interpersonalnim odnosima, slici o sebi, afektu te značajnu impulzivnost, koji počinju u ranoj odrasloj dobi i prisutni su u različitim situacijama. Predloženi dijagnostički kriteriji svrstani su u dvije osnovne skupine (A i B) koje obuhvaćaju simptome koji moraju biti prisutni da bi se postavila dijagnoza. Kriterij A odnosi se na umjereno ili teže oštećenje u funkcioniranju ličnosti, koja se očituje karakterističnim teškoćama u dva ili više od sljedećih područja: identitet, samousmjerenost, empatija i intimnost. Kriteriji B odnosi se na četiri ili više od sljedećih sedam patoloških crta ličnosti, od kojih najmanje jedna mora biti impulzivnost, poduzimanje rizika ili neprijateljstvo: emocionalna labilnost, anksioznost, separacijska nesigurnost, depresivnost, impulzivnost, poduzimanje rizika i neprijateljstvo.

DSM-V dopušta postavljanje dijagnoze poremećaja ličnosti (osim antisocijalnog poremećaja ličnosti) u adolescenciji ukoliko su simptomi dovoljno teški i interferiraju sa svakodnevnim funkcioniranjem osobe tijekom godine dana ili dulje te longitudinalna istraživanja pružaju snažne dokaze za stabilnost dijagnoze graničnog poremećaja ličnosti u adolescenciji (AP, 2010.; Winsper i sur., 2015.). 
Uvažavajući navedene klasifikacijske kriterije, potrebno je istaknuti da je prezentacija kliničkih simptoma osoba s graničnim poremećajem ličnosti koja se detektira u svakodnevnom radu vrlo široka. Osobe s ovim poremećajem ličnosti vrlo često ulažu velike napore u izbjegavanje stvarnog ili zamišljenog napuštanja, pri čemu percepcija moguće separacije ili odbijanja može dovesti do dubokih promjena slike o sebi, afekata, kognicije i ponašanja. Kako bi izbjegle »napuštanje» sklone su impulzivnim radnjama poput suicidalnog ponašanja i samoranjavanja. Ponekad misle da će zauvijek ostati sami i bez podrške tijekom svakodnevnih životnih izazova s kojima se susreću, pri čemu strah i zabrinutost zbog moguće samoće rezultiraju različitim pokušajima sprječavanja osobe da ih napusti, od moljenja osobe da ostane do fizičkog sprječavanja odlaska (APA, 2010.) i manipulativnog ponašanja koje može uključivati samoozljeđivanje i prijetnje samoubojstvom. Osobe $s$ ovim poremećajem ličnosti koriste se emocionalnim ucjenama kako bi kontrolirale bliskost $u$ interpersonalnim odnosima (Wright i sur., 2015., Tragesser i Benfield, 2012., prema Sulzer, 2015.), a da bi zadovoljile svoje emocionalne potrebe u situacijama kada im prijeti napuštanje od strane partnera, sklone su agresivnom ponašanju i ulaženju u nove višestruke odnose (Cheavens i sur., 2014.; prema Sulzer, 2015.). Zbog straha od napuštanja granični poremećaj ličnosti može doći do izražaja u situacijama razvoda braka, odnosno prekida izvanbračne zajednice, te rezultirati neprikladnim i manipulativnim ponašanjima koja obuhvaćaju niz različitih verbalnih i neverbalnih poruka kojima jedan roditelj djetetu šalje negativnu poruku o drugom roditelju s ciljem njegovog isključivanja iz života djeteta i otuđenja djeteta od roditelja bez postojanja opravdanog razloga (Gradner, 2001., prema Žakula-Desnica, 2010.). Poseban oblik manipulativnog ponašanja su lažne optužbe tijekom procesa razvoda braka i/ili odlučivanja s kojim će roditeljem dijete živjeti, a koja imaju za cilj manipulaciju pravnim, zdravstvenim i socijalnim sustavom radi dobivanja skrbništva i osvete bivšem partneru (Buljan-Flander, 2010.). Sklonost lažnim optužbama za spolno zlostavljanje djeteta od strane drugog roditelja zapažena je kod majki s graničnom strukturom ličnosti, dok očevi koji lažno optužuju bivše partnerice imaju visoko izraženu potrebu da budu »u pravu«, pretjerano su kritični prema bivšoj partnerici, smatraju da je neobazriva i nepodobna majka, češće iznose optužbe koje se odnose na nove emocionalne veze majke nego na spolno zlostavljanje, izjavljuju da bivša supruga ostavlja dijete bez nadzora, na brizi nekompetentnim i nepovjerljivim osobama ili da ih općenito izlaže opasnostima (Blush i Ross, 1987., prema Buljan Flander, 2010.).

Uzroci straha od napuštanja najčešće proizlaze iz negativnih iskustava u ranom djetinjstvu (Kresiman i Straus, 2004.). Afektivna nestabilnost i učestale promjene raspoloženja (razdoblja disforije, razdražljivosti, anksioznosti) najčešće traju nekoliko sati, a rijetko nekoliko dana. Disforično raspoloženje obično uključuje razdoblje

\section{0 članci}


bijesa, panike i očaja (APA, 2010.), iskazivanje ljutnje, tjeskobe i značajnim oscilacijama između depresije i ushićenja (Kresiman i Straus, 2004.), pri čemu blaga kritika i neodobravanje mogu rezultirati potpunim emocionalnim krahom. Osobe s ovim poremećajem često doživljavaju kroničan osjećaj praznine te konstantno traže nešto što bi mogle raditi kako bi ublažile dosadu (APA, 2010.). Osjećaj praznine teško je definirati, a najčešće se opisuje kao osjećaj beznačajnosti ili emocionalne praznine koji može dovesti do krize identiteta, promjena raspoloženja, ljutnje i samoubojstva (Kresiman i Straus, 2004.). Ispadi gnjeva često se javljaju kada smatraju da ih se zanemaruje, napušta ili da je netko nepristojan prema njima, nakon čega osjećaju sram i krivnju, a sebe doživljavaju lošima (APA, 2010.). Neki će češće osjećati ljutnju prema sebi nego prema drugima (Chapman i Gratz, 2007.). Sklonost impulzivnom ponašanju manifestiraju autodestruktivim postupcima u rasponu od suicidalnih pokušaja i samoranjavanja do riskantnih stilova života (kockanje, neodgovorno trošenje novca, upuštanje u rizične seksualne odnose, opasna vožnja i sl.). Suicidalno ponašanje je najčešći razlog da potraže pomoć. U pozadini autodestruktivnog ponašanja obično je strah od napuštanja, odbijanja ili očekivanja da preuzmu odgovornost za svoj život i postupke (APA, 2010.). Impulzivno i nekontrolirano ponašanje često im privremeno pomaže u oslobađanju od emocionalne boli. Interpersonalni odnosi ovih osoba su intenzivni i nestabilni, no u površnijem kontaktu mogu se prezentirati kao šarmantni, privlačni, zanimljivi i osjećajni (Chapman i Gratz, 2007.). Često idealiziraju druge, a već nakon prvog ili drugog susreta imaju potrebu provoditi puno vremena s njima te su im spremne otkriti najintimnije detalje iz svog života. Osciliraju od idealizacije do potpunog obezvrjeđivanja drugih. Poremećaji identiteta mogu se manifestirati kroz dramatične promjene uloga, ciljeva, vrijednosti, mišljenja, seksualnog identiteta, promjene karijere i prijatelja. Sliku o sebi obično temelje na podjeli na dobro i loše, dok u situacijama u kojima osjećaju izostanak smislenog odnosa, brige i potpore, mogu osjećati da ne postoje (APA, 2010.). U razdobljima intenzivnog stresa mogući su prolazni psihotični simptomi poput sumanutih ideja, halucinacija i disocijativnih simptoma (npr. depersonalizacija) koji mogu trajati nekoliko minuta ili sati (APA, 2010.).

Dodatnu otegotnu okolnost u dijagnosticiranju, ali i liječenju predstavljaju česti psihički i tjelesni komorbiditeti. Prema istraživanju Tomko i suradnici (2014.), $84,8 \%$ osoba s graničnim poremećajem ličnosti tijekom života imalo je anksiozni poremećaj, $82,7 \%$ poremećaje raspoloženja, a 78,2\% poremećaj ovisnosti. 


\section{LIJEČENJE GRANIČNOG POREMEĆAJA LIČNOSTI}

Liječenje osoba s graničnim poremećajem ličnosti usmjereno je na nekoliko glavnih područja: prevenciju suicidalnog ponašanja, uspostavu kontrole emocija i ponašanja, smanjivanje ili uklanjanje štetnih ovisničkih ponašanja, stabilizaciju i integraciju stila privrženosti, uspostavu i održavanje stabilnog psihičkog i fizičkog okruženja, redukciju afektivne nestabilnosti, anksioznosti i psihotičnih simptoma primjenom odgovarajućih terapijskih postupaka s ciljem očuvanja i unaprjeđenja socijalnog i radnog funkcioniranja. Liječenje započinje početnom procjenom psihijatra radi odabira odgovarajućeg tretmana. Zbog učestalog autodestruktivnog $i$ suicidalnog ponašanja, procjena sigurnosti treba biti prioritetna i temeljita, a o njoj i procjeni drugih kliničkih čimbenika, ovisi i odabir aktualnog tretmana - ambulantnog ili bolničkog liječenja pri čemu je neophodno učiniti sveobuhvatnu procjenu te na samom početku liječenja uspostaviti jasan okvir liječenja koji uključuje terapijski ugovor psihijatra i pacijenta o ciljevima liječenja (APA, 2010.).

\section{Farmakoterapija}

lako je primarni naglasak na psihoterapiji, farmakoterapija je ponekad neophodna zbog smanjivanja simptoma afektivne nestabilnosti, impulzivnosti, psihotičnih simptoma i autodestruktivnog ponašanja (APA, 2010.). Najčešće se koriste antidepresivi (selektivni inhibitori ponovne pohrane serotonina (SSRI), ali i antidepresivi drugih skupina) koji su učinkoviti u redukciji simptoma depresije, učestalih promjena raspoloženja i impulzivno-agresivnog ponašanja, uključujući redukciju autodestruktivnog ponašanja kao što je samoozljeđivanje, suicidalnost i ljutnja. Stabilizatori raspoloženja primjenjuju se u kontroli impulzivnosti i stabilizaciji raspoloženja, dok se za ublažavanje anksioznosti, ali i ljutnje, često koriste anksiolitici, poput benzodiazepina. Kod pojave psihotičnih simptoma primjenjuju se antipsihotici koji su učinkoviti i u redukciji simptoma ljutnje i impulzivnosti (Kreisman i Straus, 2004.; APA 2010.).

\section{Psihoterapija}

Primarni terapijskih tretman osoba s graničnim poremećajem ličnosti je psihoterapija. Primjenjuju se različiti psihoterapijski pristupi, a neki od najčešće korištenih su psihodinamski pristup, psihoanalitički orijentirana terapija te kognitivno-bihervioralna terapija.

\section{2 članci}


Psihodinamski i psihoanalitički pristup u fokus stavlja terapijski odnos kao primarni faktor promjene i izvor razumijevanja za klijenta i terapeuta, u okviru kojeg se nastoji omogućiti klijentu razumijevanje vlastitog unutarnjeg svijeta, što pridonosi stabilnijem i sigurnijem osjećaju vlastitog identiteta. Jedan od najčešće korištenih pristupa $s$ ovim pacijentima je psihoterapija usmjerena na transfer $\mathrm{i}$ psihoterapija temeljena na mentalizaciji (Gunderson i Hoffman, 2005.; Gunderson, 2011.). Psihoterapija usmjerena na transfer (eng. transference-focused psychotherapy) uključuje sporazum klijenta i psihoterapeuta o mjestu i vremenu provođenju terapije te kontaktima između susreta što olakšava prevladavanje poteškoća proizašlih iz transfera (Gunderson i Hoffman, 2005.). Provodi se kao individualna psihoterapija dva puta tjedno tijekom koje se putem transfera nastoje aktivirati disfunkcionalni obrasci interpersonalnih odnosa, interpretirati ih s ciljem smanjenja difuzije identiteta i unaprjeđenja reflektivnog funkcioniranja (National Collaborating Centre For Mental Health, 2009.). Drugim riječima, interpretiraju se nesvjesni motivi i osjećaji pri čemu se fokus zadržava na klijentovom pogrešnom razumijevanju ljudi, uključujući terapeuta (Gunderson, 2011.). Psihoterapija temeljena na mentalizaciji (eng. mentalization-based therapy) psihodinamski je pristup u kojem terapeut potiče klijenta da pregleda i označi vlastite i doživljaje drugih, odnosno da mentalizira. Provodi se $u$ individualnom i grupnom obliku, a naglasak je na razmišljanju prije reagiranja (Gunderson, 2011.).

U liječenju graničnog poremećaja ličnosti često se primjenjuje modificirana kognitivna bihevioralna terapija koja uzima u obzir prethodna iskustva u razvoju osnovnih uvjerenja, odnosno kognitivnih shema s ciljem prepoznavanja i mijenjanja destruktivnih obrazaca ponašanja i mišljenja (Gunderson i Hoffman, 2005.) te dijalektičko-bihevioralna terapija (eng. dialectical behavior therapy) Marshe Linehan (1993.) primarno razvijena za tretman pacijenata s graničnim poremećajem ličnosti koji imaju kronične probleme sa suicidalnim gestama i pokušajima. Ciljevi terapije usmjereni su na smanjenje rizičnih ponašanja, suočavanje s ponašanjima koja interferiraju s terapijskim procesom i modificiranje ponašanja koja značajno umanjuju pacijentovu kvalitetu života. Provodi se u obliku tjednih individualnih terapija i grupnih treninga vještina pri čemu je fokus na individualnoj terapiji koja je ujedno i preduvjet za grupni trening vještina (Gunderson i Hoffman, 2005.). Grupni trening vještina u trajanju od 2,5 sata tjedno obuhvaća četiri modula društvenih vještina: svjesnost, emocionalnu regulaciju, toleranciju na uznemirenost i interpersonalnu učinkovitost. Uz individualnu terapiju i grupni trening vještina, terapija uključuje i telefonske konzultacije čija je svrha prevencija kriznih situacija (Gunderson i Links, 2008.). 


\section{Socioterapija}

Socioterapija je dio rehabilitacije koji obuhvaća različite postupke čiji je cilj tijekom i nakon psihijatrijskog liječenja poboljšanje socijalnog funkcioniranja i socijalne prilagodbe bolesnika. Konačni je cilj cjelokupna rehabilitacija, resocijalizacija i reintegracija bolesnika u zajednicu (Ružić i sur., 2009.). Na važnost socioterapijskog pristupa ovoj kategoriji bolesnika ukazuje podatak da je u odnosu na osobe oboljele od depresije ili nekog drugog poremećaja ličnosti, kod osoba s graničnim poremećajem ličnosti veća vjerojatnost da će koristiti sve oblike psihosocijalne terapije (Kreisman i Straus, 2004.).

Socijalni radnik, kao član multidisciplinarnog tima, sudjeluje u svim fazama liječenja i rehabilitacije, ovisno o potrebama pacijenta. U okviru socioterapijskih aktivnosti socijalni radnik provodi individualne i grupne terapijske postupke, posebice savjetovanja, uključujući psihoedukaciju obitelji oboljele osobe i postupke destigmatizacije. Prilikom realizacije otpusta s bolničkog liječenja, zadaci socijalnog radnika usmjereni su na osiguranje vanbolničkog smještaja, pružanje podrške pacijentu u daljnjem liječenju, praćenje, a ukoliko je potrebno, ostvarivanje suradnje s nadležnim centrom za socijalnu skrb s ciljem osiguranja skrbi za osobu u vanbolničkom miljeu i zaštiti njihovih prava i interesa (Ostojić, 2012.; Štrkalj-Ivezić i sur., 2014.).

\section{INTERVENCIJE SOCIJALNIH RADNIKA U RADU S OSOBAMA S GRANIČNIM POREMEĆAJEM LIČNOSTI U SUSTAVU SOCIJALNE SKRBI}

Iz ranije navedenih kliničkih karakteristika osoba s graničnim poremećajem ličnosti evidentno je da se kod značajnog broja može očekivati socijalno deprivirano funkcioniranje potrebito podrške i skrbi socijalne službe i socijalnih radnika. Iz širokog spektra svojih mogućih aktivnosti, socijalna služba trebala bi se usmjeriti na osobe s ovim poremećajem, ali i na članove njihovih obitelji, posebice djecu, na planu pružanja pomoći i prevencije. Brojna istraživanja pokazuju da su osobe s ovim poremećajem zastupljene u tradicionalnim područjima socijalnog rada, a osobito među beskućnicima, siromašnim, zlostavljanom i zanemarenom djecom (Keys i Lambert, 2002.).

Intervencije socijalnih radnika u sustavu socijalne skrbi trebale bi biti usmjerene prema etiološkim čimbenicima te simptomima i poteškoćama koje proizlaze iz graničnog poremećaja ličnosti, a socijalni radnici kao profesionalci koji svakodnevno dolaze u doticaj s osobama u nepovoljnim osobnim, obiteljskim, socijalnim i eko-

\section{4 članci}


nomskim okolnostima, mogu imati ključnu ulogu u ranom prepoznavanju simptoma ovog poremećaja, u poticanju osoba na liječenje, u provođenju čitavog niza potrebitih intervencija, ali i u znanstvenom pristupu ovoj problematici (Lainer, Bollinger i Krueger, 2013.). Također, pomoć i podrška trebala bi biti usmjerena i na osobe koje skrbe o osobama s graničnim poremećajem ličnosti (Lawn i Mcmahon, 2015.).

Djelatnost socijalnih radnika u odnosu na osobe s psihičkim teškoćama uređena je Zakonom o socijalnoj skrbi, Obiteljskim zakonom, Zakonom o zaštiti osoba $s$ duševnim smetnjama te drugim pozitivnim propisima. Zakon o socijalnoj skrbi (2013., 2014., 2015., 2016., 2017.) socijalnu skrb definira kao organiziranu djelatnost od javnog interesa za Republiku Hrvatsku s ciljem pružanja pomoći socijalno ugroženim osobama i osobama u nepovoljnim osobnim i obiteljskim okolnostima, a uključuje prevenciju, promicanje promjena, pomoć u zadovoljavanju osnovnih životnih potreba, podršku pojedincu, obitelji i skupinama u svrhu unaprjeđenja kvalitete života, osnaživanja korisnika i njihove socijalne uključenosti. Korisnike u sustavu socijalne skrbi moguće je podijeliti u dvije velike skupine: osobe bez prihoda i/ili osobe s niskim prihodima koje nemaju dostatna materijalna sredstva za život te na osobe kojima su potrebne usluge i pomoć sustava socijalne skrbi zbog specifičnih potreba i životnih okolnosti. Osobe s graničnim poremećajem ličnosti u sustavu socijalne skrbi mogu se pojaviti u obje skupine korisnika, kao korisnici prava na novčana davanja i/ili prava na socijalne usluge.

Kako je ranije navedeno, brojni su biološki i psihosocijalni etiološki čimbenici koji mogu determinirati razvoj graničnog poremećaja ličnosti. Povezivanje tih etioloških čimbenika i zakonom definiranih uloga i ovlasti socijalnih radnika, ukazuje na mogućnost preventivnog djelovanja. S obzirom da se često radi o doživljenom nasilju i traumi u djetinjstvu, narušenim obiteljskim odnosima i poteškoćama u izvršavanju roditeljske skrbi, socijalni radnici s ciljem zaštite dobrobiti djeteta u mnogim situacijama morat će primijeniti neku od mjera za zaštitu prava i dobrobiti djeteta propisnih Obiteljskim zakonom (2015.). Pri donošenju odluke o izboru mjere, socijalni radnici vode se stupnjem ugroženosti djeteta u obitelji. Da bi ove mjere uistinu mogle imati svoje preventivno djelovanje, nužna je njihova pravodobna primjena. Nažalost, u praksi se često događa da centar za socijalnu skrb sazna za ugrožavanje prava i dobrobiti djeteta tek kada ono traje već duže vrijeme i kada cijela situacija kulminira, kao posljedica neprepoznavanja zlostavljanja i zanemarivanja djeteta te nepravodobnog prijavljivanja zlostavljanja i zanemarivanja djeteta od strane osoba i institucija koje o istom imaju saznanja. S obzirom da se ove mjere izriču kada su se propusti u roditeljskoj skrbi, zanemarivanje i zlostavljanje djeteta već dogodili, da bi se prevenirale moguće psihičke teškoće i poremećaji, uključujući poremećaje ličnosti, nužno je djetetu osigurati psihosocijalnu pomoć i podršku. Prema Zakonu o socijalnoj skrbi (2017., čl. 83.), psihosocijalna podrška je vrsta socijalne usluge 
koja podrazumijeva rehabilitaciju koja potiče razvoj kognitivnih, emocionalnih, komunikacijskih i socijalnih vještina. Obuhvaća individualni i grupni rad, a priznaje se djetetu s teškoćama u razvoju, odrasloj osobi s invaliditetom, ovisniku, žrtvi obiteljskog nasilja i drugim osobama u potrebi.

S obzirom da se i siromaštvo i nizak socioekonomski status potencijalno dovode u vezu s razvojem graničnog poremećaja ličnosti, mogućnost preventivnog djelovanja socijalnih radnika ogleda se kroz pružanje podrške u osiguravanju egzistencijalnog minimuma. Ovisno o ispunjavanju zakonski propisanih uvjeta, osobe s ovim poremećajem mogu ostvariti pravo na novčana davanja kao što su zajamčena minimalna naknada i jednokratna novčana naknada. Međutim, treba istaknuti da je riječ o vrlo niskim naknadama (primjerice, iznos zajamčene minimalne naknade za radno sposobnog samca iznosi $800,00 \mathrm{kn}$ ) koje u stvarnosti ne mogu pokriti ni osnovne životne potrebe, stoga se postavlja pitanje je li u ovom kontekstu uopće moguće govoriti o preventivnom djelovanju. Također, određeni podaci ukazuju na smanjenu fizičku i psihičku sposobnost osoba s graničnim poremećajem ličnosti pri čemu značajan broj ovih osoba u određenom periodu života koristi invalidninu (Zanarini i sur., 2009., prema Zimmerman i sur., 2012.), dok je samo jedna trećina osoba s graničnim poremećajem ličnosti u desetogodišnjem periodu radila puno radno vrijeme (Gunderson i sur., 2011., prema Zimmerman i sur., 2012.). Biti korisnikom invalidnine neovisno radi li se o kraćem ili dužem vremenskom periodu, kao i rad s polovicom punog radnog vremena, stavlja osobu u nepovoljan socioekonomski položaj. Podaci analize siromaštva i invaliditeta Udruženja za razvojnu politiku (Leutar, 2006.) govore o uskoj povezanosti invaliditeta i siromaštva pri čemu invaliditet vodi siromaštvu, a siromaštvo pogoršanju zdravlja i progresiji postojećeg invaliditeta. Socijalni rad kao profesija koja je svakodnevno u doticaju sa siromaštvom trebala bi iskoristiti iskustvo rada s korisnicima kako bi snažnije utjecala na socijalnu politiku i njezine mjere te na taj način pridonosila prevenciji siromaštva, a posredno $i$ prevenciji graničnog poremećaja ličnosti.

Radi prevladavanja poteškoća u vezi s bolešću i stvaranja uvjeta za očuvanje i razvoj osobnih mogućnosti i odgovornog odnosa prema sebi i drugima, osobama s ovim poremećajem može se priznati pravo na socijalnu uslugu savjetovanja i pomaganja pojedincu (Zakon o socijalnoj skrbi, 2013., 2014., 2015., 2016., 2017., čl. 78.). Tijekom savjetovanja, korisnik i savjetovatelj razvijaju odnos povjerenja i međusobne suradnje u kojem se nastoji korisnika potaknuti da govori o vlastitim osjećajima i problemima, pomoći mu da bolje razumije sebe i situaciju u kojoj se nalazi te da sam donosi odluke s ciljem rješavanja problema i poteškoća u kojima se nalazi. Zbog komorbiditeta graničnog poremećaja ličnosti i zlouporabe sredstava ovisnosti, suočavanja s različitim oblicima nasilja, osobe s ovim poremećajem ličnosti u sustavu socijalne skrbi često se pojavljuju i kao korisnici prava na psihosocijalnu

\section{6 članci}


podršku. Tijekom psihosocijalne podrške stječu znanja i vještine za suočavanje i borbu s ovisnošću, uključujući i vještine za uspješno nošenje sa simptomima graničnog poremećaja ličnosti. Osnažuje in se kako bi pronašli i stekli snage za uspješno nošenje sa životnim nedaćama i stresom te im se pomaže razvijati komunikacijske i socijalne vještine radi unaprjeđenja interpersonalnih odnosa i života u zajednici.

Socijalne usluge značajne su u rješavanja problema u obiteljskim i partnerskim odnosima u smislu podučavanja komunikacijskim vještinama i strategijama, tehnikama samokontrole i drugo. Osobe s ovim poremećajem osciliraju u doživljaju drugih osoba, od idealizacije do devaluacije. lako često odbacuju bliske odnose, od istih očekuju stabilnost i ravnotežu, u suprotnom reagiraju ispadima bijesa i depresivnosti (Kresiman i Straus, 2004.). Nestabilnost slike o sebi i raspoloženja mogu rezultirati ograničenom sposobnošću predanosti u bliskim odnosima (Bouchard i Sabourin, 2009., prema de Montigny-Malenfant i sur., 2013.). Prema podacima istraživanja Bouchard i suradnika (2009.) partnerske veze u kojima žena ima granični poremećaj ličnosti, obilježene su periodima prekida i mirenja pri čemu je oko $30 \%$ parova tijekom 18-mjesečnog perioda okončalo svoju vezu. Česta su negativna ponašanja, osobito dominacije pri čemu žene češće kao oblike ponašanja usvajaju kriticizam, napad i konflikt (de Montigny-Malenfant i sur., 2013.). Učestali prekidi veza ukazuju na visoke stope razvoda zbog čega su od velikog značaja instituti obveznog savjetovanja i obiteljske medijacije u situacijama kada partneri imaju zajedničku maloljetnu djecu ili djecu nad kojom ostvaruju roditeljsku skrb. Upoznavanje s mogućnostima bračnog savjetovanja i psihosocijalnim posljedicama braka izrazito je važno za osobe s graničnim poremećajem ličnosti. Kao što je prethodno navedeno, partnerske veze osoba s ovim poremećajem obilježene su periodima prekida i mirenja, međutim ne završe sve veze prekidom (Bouchar i sur., 2009.). Uzimajući to u obzir, postoji mogućnost da će bračni partneri uz pomoć i podršku bračnog savjetovatelja riješiti svoje probleme i odustati od razvoda. Ukoliko ipak dođe do razvoda, s obzirom na strah od napuštanja s kojim se suočavaju osobe oboljele od ovog poremećaja ličnosti, podrška i pomoć stručne osobe, odnosno savjetovatelja olakšat će im suočavanje s razvodom i proces prilagodbe na novonastalu situaciju.

Osim usluga savjetovanja i psihosocijalne podrške, osobe s graničnim poremećajem ličnosti mogu ostvariti pravo na privremeni smještaj radi provođenja kraćih rehabilitacijskih programa i pravo na privremeni smještaj u kriznim situacijama (Zakon o socijalnoj skrbi, 2013., 2014., 2015., 2016., 2017., čl. 89.).

Sagledavajući socijalnu komponentu složene problematike graničnog poremećaja ličnosti, važno je istaknuti da se osobe s ovim poremećajem ličnosti, osim kao žrtve nasilja, mogu pojaviti i kao počinitelji nasilja. Postoje podaci koji ukazuju na veću vjerojatnost da će žene s graničnim poremećajem ličnosti biti počiniteljice intimnog nasilja u vezama nego žrtve što se objašnjava učestalom psihičkom 
i fizičkom agresijom koja je potencijalno povezana s ovim poremećajem (Clifft i Dutton, 2011., prema Jackson i sur., 2015.). Također, više je osoba s karakteristikama graničnog poremećaja ličnosti među muškim počiniteljima seksualnog nasilja u vezama u odnosu na muškarce koji ne iskazuju nasilne oblike ponašanja (Edwards i sur., 2003.; Porcerelli, Cogan i Hibbard, 2004.; Costa i Babcock, 2008.; prema Jackson i sur., 2015.; Peters, Derefinko i Lynam, 2017.). U ovakvim situacijama ranije spomenute mjere za zaštitu prava i dobrobiti djeteta bit će usmjerene prema osobama s graničnim poremećajem ličnosti pod uvjetom da imaju djecu nad kojom ostvaruju roditeljsku skrb, ali i prema žrtvama nasilja.

Moguće poteškoće u odgoju i skrbi za dijete majki s graničnim poremećajem ličnosti determinirane su nizom čimbenika (Stepp i sur., 2012.) koje pri planiranju socijalnih intervencija svakako treba akceptirati. Već od rođenja djeteta majke se mogu osjećati otuđeno, anksiozno i ljuto u odnosu na dijete (Newman i Stevenson, 2005., prema Newman i sur., 2007.), nedosljedno odgovarati na djetetove potrebe i pogrešno tumačiti djetetove emocije (Bland i sur., 2004., prema Newman i sur., 2007.). U odnosu na majke bez poremećaja ličnosti, majke s graničnim poremećajem ličnosti mogu biti manje osjetljive, iskazivati manju strukturiranost $u$ interakciji s djetetom, dok njihova djeca pokazuju manju zainteresiranost i želju za interakcijom s majkom. Također, ove se majke mogu osjećati uznemireno, zabrinuto i nekompetentno u svojoj roditeljskoj ulozi (Newman i sur., 2007., Zalewski i sur., 2015.) pri čemu se često suočavaju s izostankom partnerove podrške u izvršavanju roditeljske uloge (Barnow i sur., 2006., Crittenden i Newman, 2010., prema Patefield i sur., 2017.). Obiteljsko okruženje može karakterizirati niska kohezija i visoka razina sukoba pri čemu djeca često svjedoče nasilju i suicidalnim pokušajima majki (Feldman i sur., 1995., prema Patefield i sur., 2017.). Radi prevladavanja obiteljskih poteškoća u odgoju i skrbi za djecu te osposobljavanja obitelji za svakodnevno funkcioniranje, može se priznati pravo na socijalnu uslugu savjetovanja i pomaganja obitelji koja uključuje intenzivnu podršku obitelji u krizi i dugoročan rad s obitelji (Zakon o socijalnoj skrbi, 2013., 2014., 2015., 2016., 2017., čl. 78.).

Važno je istaknuti da neovisno o tome koja će se mjera obiteljsko-pravne zaštite izreći prema roditeljima s graničnim poremećajem ličnosti i koju socijalnu uslugu će koristiti svaka od tih intervencija podrazumijeva intenzivan rad usmjeren na pružanje pomoći i podrške s ciljem unaprjeđenja roditeljskih sposobnosti i kapaciteta te uspješnog nošenja s teškoćama koje su posljedica simptoma graničnog poremećaja ličnosti.

U radu s osobama s graničnim poremećajem ličnosti vrlo je važno da intervencije socijalnih radnika uključuju osnaživanje i destigmatizaciju koje se provode u okviru različitih socijalnih usluga. U procesu destigmatizacije važnu ulogu zauzima edukacija u obliku otvorene diskusije o simptomima bolesti, njezinim psihološkim i socijalnim posljedicama u kontekstu oporavka kako bi oboljela osoba i članovi njezine obitelji

\section{8 članci}


što bolje razumjeli psihičku bolest, simptome i prevenciju recidiva, uključujući prepoznavanje simptoma bolesti, razumijevanje njihovog nastanka, postupka liječenja i samopomoći (Clark, 1965., Clark 1996., Davenport, 1997., Davenport, 2000., Campling i Farquharson, 2004., Hardcastle i sur., 2007., prema Štrkalj-Ivezić i Martić-Biočina, 2010.). Proces osnaživanja uključuje osobnu, interpersonalnu i institucionalnu dimenziju (Lee i Gutiéreez, 1994., prema Kletečki, 2008.). Na osobnoj razini zadatak socijalnog radnika usmjeren je na pružanje pomoći pojedincu u prepoznavanju izvora nemoćnosti i redefiniranju sebe u pozitivnijem samoodređujućem svjetlu perspektivne snage, uključujući svijest o negativnim procjenama doživljenim u životu te prepoznavanje zapreka koje sprječavaju osobni i socijalni rast. Koristi se samoreflektiranje i dijalog da bi se izdvojile negativne procjene i zapreke s ciljem otvaranja prostora za rast i razvoj pozitivnijih, otpornijih i snažnijih dijelova ličnosti (Kletečki, 2008.). Na interpersonalnoj razini socijalni radnici da bi pomogli ljudima u prevladavanju stigmatizacije koriste svoja znanja o razvoju snaga kod pojedinca, obitelji, grupe i zajednice pri čemu je važno pomoći korisnicima da razumiju fizičke, psihološke i socijalne aspekte problema, razvijati nove vještine poput zastupanja, samozastupanja i medijacije te pomoći im u organiziranju i korištenju grupa za pomoć i samopomoć (Gutiérrez, Parsons i Cox, 2003., prema Kletečki, 2008.). Na institucionalnoj razini zadaci socijalnih radnika usmjereni su na pružanje pomoći pojedincima, grupama i zajednicama u razvoju znanja i vještina potrebnih za prepoznavanje i utjecaj na političke procese (Robbins, Chatterjee i Canda, 1998., prema Kletečki, 2008.).

\section{ZAKLJUČAK}

Osobe s graničnim poremećajem ličnosti često su potrebite intervencija socijalne službe uslijed brojnih simptoma koji mogu značajno narušiti njihovo osobno, obiteljsko, socijalno i radno funkcioniranje. Socijalni radnici iz sustava socijalne skrbi koji u svom radu redovito dolaze u doticaj s osobama u nepovoljnim osobnim, obiteljskim i ekonomskim situacijama trebali bi imati ključnu ulogu u prepoznavanju simptoma graničnog poremećaja ličnosti, u poticanju i upućivanju osoba na liječenje, dok bi socijalni radnici zaposleni u sustavu zdravstva, kao članovi multidisciplinarnog tima, trebali sudjelovati u svim fazama liječenja i zajedno s kolegama iz sustava socijalne skrbi osigurati ostvarivanje prava oboljelim osobama.

Razvoj i prezentacija graničnog poremećaja ličnosti povezani su s nizom čimbenika koji su u djelokrugu profesije socijalnog rada. Pravovremeno prepoznavanje tih čimbenika (primjerice, zlostavljanje i zanemarivanje djece, nasilje u partnerskim i obiteljskim odnosima, nepovoljne socioekonomske okolnosti i sl.) omogućilo bi preventivno djelovanje na razvoj ovog poremećaja te bi reduciralo nepovoljne psihosoci- 
jalne implikacije. Navedeno bi, uz izricanje mjera obiteljsko-pravne zaštite, priznavanje statusa korisnika prava i socijalnih usluga u okviru sustava socijalne skrbi pridonijelo uspješnijem tretmanu, rehabilitaciji i resocijalizaciji te unaprjeđenju dobrobiti osoba s graničnim poremećajem ličnosti, ali i dobrobiti članova njihove obitelji.

Potrebno je istaknuti da do sada u našoj zemlji nema dostatnih istraživanja složene problematike međusobnog odnosa osoba s graničnim poremećajem ličnosti i intervencija iz područja socijalne zaštite. S obzirom na važnost ovog područja, svakako su potrebna daljnja istraživanja.

\section{LITERATURA}

1. American Psychiatric Association (2010). Practice guideline for the treatment of patients with borderline personality disorder. Washington: American Psychiatric Association.

2. Američka psihijatrijska udruga (2014). Dijagnostički istatistički priručnikza duševne poremećaje DSM-5. Zagreb: Naklada Slap.

3. Beauchaine, T.P., Crowell, S. E. \& Linehan, M. M. (2009). A biosocial developmental model of borderline personality: Elaborating and extending Linehan's theory. Psychological Bulletin, 135 (3), 495-510, https://doi.org/ 10.1037/a0015616

4. Begić, D. (2011). Psihopatologija. Zagreb: Medicinska naklada.

5. Black, D. W., Blum, N., Pfohl, B. \& Hale, N. (2004). Suicidal behavior in borderline personality disorder: Prevalence, risk factors, prediction, and prevention. Journal of Personality Disorders, 18 (3), 226-239, https://doi.org/ 10.1521/ pedi.18.3.226.35445

6. Bouchard, S., Sabourin, S., Lussier, Y. \& Villeneuve, E. (2009). Relationship quality and stability in couples when one partner suffers from borderline personality disorder. Journal of Marital and Family Therapy, 35 (4), 446-455. https://doi.org/10.1111/j.1752-0606.2009.00151.x

7. Buljan Flander, G. (2010). Lažne optužbe za zlostavljanje djece tijekom razvoda braka. U: Osmak-Franjić, D. (ur.), Djeca i konfliktni razvodi: Zbornik priopćenja s Godišnje konferencije Mreže pravobranitelja za djecu Jugoistočne Europe i stručnih rasprava Pravobranitelja za djecu RH. Zagreb: Pravobranitelj za djecu, 95-103.

8. Chapman, A. \& Gratz, K. (2007). The borderline personality disorder survival guide: Everything you need to know about living with BPD. New Harbinger Publications.

9. Cohen, P., Chen, H., Gordon, K., Johnson, J., Brook, J. \& Kasen, S. (2008). Socioeconomic background and the developmental course of schizotypal and borderline personality disorder symptoms. Development and Psychopathology, 20 (2), 633-650. https://doi.org/10.1017/S095457940800031X

\section{0 članci}


10. Crowell, S. E., Beauchaine, T. P. \& Linehan, M. M. (2009). A biosocial developmental model of borderline personality: Elaborating and extending linehan's theory. Psychological Bulletin, 135 (3), 495. https://doi.org/10.1037/a0015616

11. de Montigny-Malenfant, B., Santerre, M. W., Bouchard, S., Sabourin, S., Lazariders, A. \& Belanger, C. (2013). Couples' negative interaction behaviors and borderline personality disorder. The American Journal of Family Therapy, 41, 259-271. https:// doi.org/10.1080/01926187.2012.688006

12. Družić Ljubotina, O. \& Ljubotina, D. (2014). Odnos siromaštva i nekih aspekata psihološke dobrobiti. Socijalna psihijatrija, 42, 86-101.

13. Elliot, R., Campbell, L., Hunter, M., Cooper, G., Melville, J., McCabe, K., Newman, L. \& Loughland, C. (2014). When I look into my baby's eyes.... Infant emotion recognition by mother with borderline personality disorder. Infant Health Menatal Journal, 35 (1), 21-32. https://doi.org/ 10.1002/imhj.21426

14. Grant, B. F., Chou, S. P., Goldstein, R. B., Huang, B., Stinson, F. S., Saha, T. D., Smith S. M., Dawson D. A., Pulay, A. J., Pickering, R. P. \& Ruan, W. J. (2008). Prevalence, correlates, disability, and comorbidity of DSM-IV borderline personality disorder: Results from the wave 2 national epidemiologic survey on alcohol and related conditions. The Journal of Clinical Psychiatry, 69 (4), 533.

15. Gunderson, J. G. \& Links, P. S. (2008). Borderline personality disorder: A clinical guide. Arlington: American Psychiatric Publishing, Inc.

16. Gunderson, J. G. (2011). A BPD brief: An introduction to borderline personality disorder:Diagnosis, originis, course and treatment. Preuzeto s: https://www.borderlinepersonalitydisorder.com/wp-content/uploads/2011/07/A_BPD_Brief_REV2011-1. pdf (3.2.2018)

17. Gunderson, J. G. \& Hoffman, P. D. (2005.). Understanding and treating borderline personality disorder: A guide for professionals and families. Arlington: American Psychiatric Publishing, Inc.

18. Hoffman, P. J. \& McGlashan, T. H. (2003). A developmental model of borderline personality disorder: Understanding variations in course and outcome. Whasington, London: American Psychiatric Pub.

19. Holthausen, B. S. \& Habel, U. (2018). Sex differences in personality disorders. Current psychiatry reports, 20 (12), 107. https://doi.org/10.1007/s11920-018-0975-y

20. Hrvatski zavod za javno zdravstvo (2012). Međunarodna statistička klasifikacija bolesti i srodnih zdravstvenih problema, Deseta revizija, Svezak 1. Zagreb: Medicinska naklada.

21. Jackson, M. A., Sippel, L. M., Mota, N., Whalen, D. \& Schumacher, J. A. (2015). Borderline personality disorder and related constructs as risk factors for intimate partner violence perpetration. Aggression and Violent Behavior, 24, 95-106. https://doi.org/10.1016/j.avb.2015.04.015 
22. Keys, D. \& Lambert, G. (2002). Concept of 'personality disorder'and its relationship to social work. Australian Social Work, 55 (3), 161-171. https://doi. org/10.1080/03124070208410972

23. Kletečki, M. (2008). Teorija osnaživanja u socijalnom radu. Ljetopis socijalnog rada, 15 (2), 215-242.

24. Kreisman, J. J. \& Straus, H. (2004). Sometimes I act crazy: Living with borderline personality disorder. New York: John Wiley \& Sons.

25. Larsen, R. J. \& Buss, D. M. (2008). Psihologija ličnosti. Jastrebarsko: Naklada Slap.

26. Lawn, S.\& Mcmahon, J. (2015.). Experiences of family carers of people diagnosed with borderline personality disorder. Journal of Psychiatric and Mental Health Nursing, 22, 234-243. https://doi.org/10.1111/jpm.12193

27. Leutar, Z. (2006). Osobe s invaliditetom i siromaštvo. Revija za socijalnu politiku, 13 (3-4), 293-308.

28. Linehan, M. (1993). Cognitive-behavioral treatment of borderline personality disorder. New York: Guilford Press.

29. Mimica, N. \& Gregurek, R. (2006). Poremećaji ličnosti. U: Hotujac, Lj. (ur.), Psihijatrija. Zagreb: Medicinska naklada, 244-251.

30. Murphy, N. \& McVay, D. (2010). Treating personality disorder. London, New York: Routledge.

31. National Collaborating Centre for Mental Health (2009). Borderline personality disorder: Treatment and management. Preuzeto s: https://www.ncbi.nlm.nih.gov/ pubmed/21796831 (21.1.2019.).

32. Newman, L. K., Stevenson, C. S., Bergman, L. R. \& Boyce, P. (2007). Borderline personality disorder, mother-infant interaction and parenting perceptions: Preliminary findings. Australian \& New Zealand Journal of Psychiatry, 41 (7), 598-605, https://doi.org/10.1080/00048670701392833

33. Obiteljski zakon. Narodne novine, 103/2015.

34. Ostojić, D. (2012). Prva epizoda shizofrenije - važnost ranog otkrivanja bolesti: Što o tome trebaju znati socijalni radnici? Ljetopis socijalnog rada, 19 (1), 53-72.

35. Peters, J. R., Derefinko, K. J. \& Lynam, D. R. (2017). Negative urgency accounts for the association between borderline personality features and intimate partner violence in young men. Journal of Personality Disorders, 31 (1), 16-25. https://doi. org/10.1521/pedi_2016_30_234

36. Patefield, L., Startup, H., Droscher, H. \& Cartwright-Hatton, S. (2015). Parenting in mothers with borderline personality disorder and impact on child outcomes. Evidence-based Mental Health, 18 (3), 67-75, https://doi.org/10.1136/eb2015-102163

37. Ružić, K., Medved, P., Dadić-Hero, E. \& Tomljanović, D. (2009). Rehabilitacija u psihijatriji-socioterapija. Medicina Fluminensis, 45 (4), 338-343.

\section{2 članci}


38. Sher, L., Rutter, S. B., New, A. S., Siever, L. J. \& Hazlett, E. A. (2019). Gender differences and similarities in aggression, suicidal behaviour, and psychiatric comorbidity in borderline personality disorder. Acta Psychiatrica Scandinavica, 139 (2), 145-153. https://doi.org/10.1111/acps.12981

39. Silberschmidt, A., Lee, S., Zanarini, M. \& Schulz, S. C. (2015). Gender differences in borderline personality disorder: Results from a multinational, clinical trial sample. Journal of Personality Disorders, 29 (6), 828-838. https://doi.org/10.1521/ pedi_2014_28_175

40. Stepp, S. D., Whalen, D. J., Pilkolins, P. A., Hipwell, A. E. \& Levine, M. D. (2012.). Parenting behaviors of mothers with borderline personality disorder: A call to action. Personality Disorders: Theory, Research, and Treatment, 3 (1), 104-106. https://doi.org/10.1037/a0026086

41. Sulzer, S. H. (2015). Does »difficult patient« status contribute to de facto demedicalization? The case of borderline personality disorder. Social Science \& Medicine, 142, 82-89. https://doi.org/10.1016/j.socscimed.2015.08.008

42. Štrkalj-Ivezić, S., Jendričko, T., Pisk, Z. \& Martić-Biočina, S. (2014). Terapijska zajednica. Socijalna psihijatrija, 42 (3), 172-179.

43. ten Have, M., Verheul, R., Kaasenbrood, A., van Dorsselaer, S., Tuithof, M., Kleinjan, M. \& de Graaf, R. (2016). Prevalence rates of borderline personality disorder symptoms: A study based on the Netherlands mental health survey and incidence study-2. BMC psychiatry, 16 (1), 249. https://doi.org/ 10.1186/s12888-016-0939-x

44. Tomko, R. L., Trull, T. J., Wood, P. K. \& Sher, K. J. (2014). Characteristics of borderline personality disorder in a community sample: Comorbidity, treatment utilization, and general functioning. Journal of Personality Disorders, 28 (5), 734. https://doi. org/10.1521/pedi_2012_26_093

45. Winsper, C., Marwaha, S., Lereya, S. T., Thompson, A., Eyden, J. \& Singh, S. P. (2015). Clinical and psychosocial outcomes of borderline personality disorder in childhood and adolescence: A systematic review. Psychological Medicine, 45 (11), 2237-225, https://doi.org/10.1017/S0033291715000318

46. Zakon o socijalnoj skrbi, Narodne novine, 157/2013., 152/2014., 99/2015., 52/2016., 16/2017., 130/2017.

47. Zalewski, M., Steep, S. D., Whalen, D. J. \& Scott, L. N. (2015.). A qualitative assessment of the parenting challenges and treatment needs of mothers with borderline personality disorder. Journal of Psychotherapy Integration, 25 (2), 71-89. https://doi.org/10.1037/a0038877

48. Zimmerman, M., Martinez, J. H., Young, D., Chelminski, I. \& Dalrymple, K. (2012). Sustained unemployment in psychiatric outpatients with bipolar depression compared to major depressive disorder with comorbid borderline personality disorder. Bipolar Disorders, 14 (8), 856-862, https://doi.org/s10.1111/bdi.12014 
49. Žakula Desnica, T. (2010). Nekvalitetan razvod i manipulacija djecom. U: Osmak-Franjić, D. (ur.), Djeca i konfliktni razvodi: Zbornik priopćenja s Godišnje konferencije Mreže pravobranitelja za djecu Jugoistočne Europe i stručnih rasprava Pravobranitelja za djecu RH. Zagreb: Pravobranitelj za djecu, 133-138.

Ivana Maljuna

Draženka Ostojić

Tihana Jendričko

University Psychiatric Hospital Vrapče

\section{PSYCHOSOCIAL ASPECTS OF BORDERLINE PERSONALITY DISORDER}

\section{ABSTRACT}

Borderline personality disorder most commonly occurs in late adolescence or young adulthood, while its most clear presentation appears in adulthood, upon completion of psychological maturation. The symptoms of the disorder are manifested by unstable affect, impulsive behaviour, identity disorder, unstable interpersonal relationships and possible errors in reality testing, which can all lead to significant difficulties in personal, familial, parental, social and work functioning. Frequent comorbidities (affective disorders, anxiety and substance abuse, etc.) are further aggravating factors in terms of prognosis. Etiological factors of the disorder are numerous and not well known, but present findings indicate that they include an interaction of biological predispositions and environmental factors. In the treatment and care of persons with borderline personality disorder, in addition to psychotherapy and sociotherapy (and pharmacotherapy if necessary), comprehensive psycho-social interventions are essential, where social workers play a key role. Timely identification of etiological factors and measures within the competence of social workers in the welfare system can contribute to the prevention of this personality disorder, while measures and interventions applied to the affected persons can contribute to their rehabilitation and well-being, as well as the well-being of their family members.

Key words: borderline personality disorder, social worker, psycho-social interventions.

Međunarodna licenca / International License:

Creative Commons Attribution-NonCommercial-NoDerivatives 4.0.

\section{4 članci}

